\title{
Determination of Ecological Footprint at the Prefectural Level in Japan from the Perspective of the Consumption of Resources and Energy
}

\author{
Takahiro SUZUKI ${ }^{\dagger}{ }^{\dagger}$ and Kazutoshi TANABE $* 2$ \\ (Received June 20, 2016)
}

\author{
資源・エネルギー消費からみた都道府県別エコロジカル・フットプリント值の算出 \\ 鈴木孝弘 $* 1 \dagger ，$ 田辺和俊 $* 2$
}

\begin{abstract}
Ecological footprint (EF) is a measure to evaluate the human impact on the earth recently. The purpose of this study is to evaluate prefectural $\mathrm{EF}$ values in 2010 from available energy and material consumption data. The prefectural EFs are calculated based on six categories; "forest area for assimilating $\mathrm{CO}_{2}$ ", "cropland", "fishing grounds", "forest area for product paper and/or timber", "grazing land", and "built-up land" according to the definition by World Wide Fund for Nature (WWF). The resulting prefectural EF values are higher in the local prefectures having heavy and chemical industries, especially in Yamaguchi, Oita, Okayama, and Hiroshima. However, the other areas relate closely to the energy and material consumption from these prefectures. Therefore, in addition, the prefectural EFs are reevaluated by employing the mean value of $\mathrm{CO}_{2}$ amount of emission from an industry section. The difference of the EF values between 47 prefectures became small and higher EF values are found in Hokkaido, Tokyo, Okinawa, and prefectures in the Tohoku and Chugoku regions. The reason is coming from that of $\mathrm{CO}_{2}$ amount of emission from a consumer section in such prefectures, which is larger than other prefectures. For the total environmental load, which can be calculated from the manipulation of population and $\mathrm{EF}$ value in each prefecture, the value becomes higher at densely populated urban and rural prefectures such as Tokyo, Kanagawa, Osaka, Aichi, Saitama, Hokkaido, and Chiba.
\end{abstract}

\section{Key Words}

Carbon dioxide emission, Ecological footprint, Prefectural ecological footprint, Sustainability

人間活動にともなう地球の持続可能性を評価する指標の 1 つに, エコロジカル・フットプリント $(\mathrm{EF})$ がある。本研究では, 47 都道府県のエネルギーと資源の消費データ基づき，グローバル・フットプリント・ネットワーク（GFN）が算出した 2010 年の日本の $\mathrm{EF}$ 值を各都道府県に割り当てることを試みた。都道府県の EF は，世界自然保護基金（WWF）の定義による カーボン・フットプリント, 耕作地, 牧草地, 漁場, 森林地, 生産能力阻害地の6つのカテゴリーに分けて計算した。その 結果, 鉄鋼や石油化学などの重化学工業の立地県 (山口, 大分, 岡山, 広島, 和歌山など) が $\mathrm{EF}$ 值で上位 5 県を占めるが, これらの県は都道府県別の総環境負荷量 $(\mathrm{EF} \times$ 都道府県人口) でみると, 人口規模が大きくないため 9 位以下になり, 東京, 神奈川, 愛知, 大阪などの大都市圈が上位を占めた。さらに, 他地域での都市活動等が影響する産業によるエネルギー消 費 $\left(\mathrm{CO}_{2}\right.$ 排出量 $)$ を 47 都道府県の平均值を用いて $\mathrm{EF}$ を再評価した。その $\mathrm{EF}$ 值でみると, 都道府県間の相違は減少したが, 民生からの $\mathrm{CO}_{2}$ 排出量が多い北海道·東北地方, 東京, 中国地方, 沖縄等の $\mathrm{EF}$ 值が全国平均より高い傾向が認められた。 その各都道府県の $\mathrm{EF}$ 值に都道府県人口を乗じて求めた総環境負荷量では, 東京, 神奈川, 大阪, 愛知, 埼玉, 北海道, 千葉を初めとする人口規模の大きな都道府県で総環境負荷量が多いことを明らかにできた。

キーワード

$\mathrm{CO}_{2}$ 排出量, エコロジカル・フットプリント, 都道府県の $\mathrm{EF}$, 持続可能性

※1 Department of Economics, Faculty of Economics, Toyo University

5-28-20, Hakusan, Bunkyo-ku, Tokyo 112-8606, Japan

$※ 2$ Institute of Social Sciences, Toyo University

5-28-20, Hakusan, Bunkyo-ku, Tokyo 112-8606, Japan

$\dagger \quad$ Corresponding author: suzuki@toyo.jp
※1 東洋大学大学院経済学研究科経済学専攻 于 112-8606 東京都文京区白山 5-28-20

※2 東洋大学現代社会総合研究所 干 112-8606 東京都文京区白山 5-28-20 


\section{1. はじめに}

近年, 人間活動にともなう「持続可能性」を評価する指標 の一つとして，エコロジカル・フットプリント (EF) 1) 2) が世 界的に注目されている。 $\mathrm{EF}$ は， 1 年間に 1 人の人間が食料 消費や資源消費， $\mathrm{CO}_{2}$ 排出などの普通の生活を営むために 必要な土地や海の面積のことである。これによると, 現代の 日本人が 1 年間生活するために必要な土地の面積は東京ドー ム 1 個分 (4.7 ha) 程度のレベルと見積もられている。すな わち, 建設物の面積 (0.04 gha), 米や麦の栽培に必要な耕 作地 (0.47 gha), 魚介類を獲るための海の面積 (0.47 gha), 肉や乳製品を生産するための家畜の放牧地 (0.16 gha), 紙 やパルプの製造に必要な森林 (0.23 gha), そしてエネル ギーの発生や $\mathrm{CO}_{2}$ の吸収に必要な森林 (2.54 gha) の合計 $3.90 \mathrm{gha}(2010$ 年) である。現在 73 億人を超えた世界中の人々 が日本人と同じような暮らしをすると, 地球が約 2.3 個必要 になり，途上国の人々に貧困や食糧不足といった形でしわ寄 せがいっていることがわかる。また， $\mathrm{CO}_{2}$ の吸収に必要な森 林が全 EF の約 65\%を占めている。

$\mathrm{EF}$ をバイオキャパシティ(生物生産力) ${ }^{3)}$ と比較すると, 人間の経済活動が現在の地球上で持続可能かあるいは需要 過剰(オーバーシュート $)^{1}$ かを判定できる ${ }^{4)}$ 。そのため, 国連, 各国政府，自治体，各種団体，民間企業等の環境調查や政 策立案，環境教育等に幅広く活用されている5）6）日本でも 2006 年, 第三次環境基本計画の中に $\mathrm{EF}$ の利用が盛り込ま れた。 $\mathrm{EF}$ は国レベル以外に, 地域レベルで持続可能な発展 を図るためのローカル指標として活用していくことが求められ ている。

東京都では，日本人 1 人当たりと東京都民 1 人当たりの $\mathrm{EF}$ 值が等しいという仮定の下に東京都の $\mathrm{EF}$ を試算してお り，それが都の面積の 125 倍と見積もっている7)。しかし， その $\mathrm{EF}$ 值は，実際の東京都民の資源消費量から求められ たものではない。谷口ら ${ }^{6)}$ は消費量とそれに直接かかわった 面積に基づいて都道府県別の $\mathrm{EF}$ を算出しているが, 生産か ら最終的な消費までに他産業を通じて間接的に利用する $\mathrm{EF}$ を考慮できないという久点が指摘されている9)。Hasegawa ら 10) も都道府県別の $\mathrm{CO}_{2}$ 排出量を産業連関分析の手法に基 づき見積もる方法を提案している。岡山県津山市では都市 計画マスタープランで, $\mathrm{EF}$ 值を指標の一つとして用いるため に環境負荷超過率の評価が試みられた 9)。しかし，これま でのところ $\mathrm{EF}$ の計算には課題もあり，その改良が試みられ てきている11)12)。

$\mathrm{EF}$ の算出には，その定義に基づいて人間の生活に必要な 6 土地区分, 農地, 牧草地, 木材を採る森林, 排出 $\mathrm{CO}_{2}$ の 吸収に必要な森林面積, 生産能力阻害地 (建物や道路等), 海洋淡水域ごとに国内の生産活動および輸入物の生産で使 用される土地使用量を計算する必要がある。2009 年 9 月, $\mathrm{EF}$ の算出基準として「Ecological Footprint Standards 2009」 が発表されたが，計算手順の複雑さ，詳細なデー夕の必要 性等の課題がある ${ }^{13)}$ 。前報 ${ }^{14)}$ では, 世界162 か国の $\mathrm{EF}$ のデー 夕を目的変数とし, 32 種の様々な分野の要因を説明変数とし,
非線形回帰分析手法であるサポートベクターマシン (SVM) を用いて EF の決定要因の解析を試みた。その結果, 世界 的にみて, エネルギー消費と何らかの関係のある要因が $\mathrm{EF}$ 值の決定に最も大きな寄与を占めていることを確認できた。

本研究では, 日本全体の $\mathrm{EF}$ 值と各都道府県の消費デー タから都道府県別の $\mathrm{EF}$ 值を割り当てることを目的とした。 さらに都道府県別のエネルギー消費量と $\mathrm{EF}$ 值との関係を検 討した。

\section{2. 方 法}

\section{$2.1 E F$ のデータ}

$\mathrm{EF}$ 值は幾つかの機関から公表されているが, 本研究では グローバル・フットプリント・ネットワーク (Global Footprint Network, GFN）が算出し，世界自然保護基金（WWF）が 公表している Living Planet Report 2000 ～ 2014 のデータを 参照した。WWFによる消費に関する $\mathrm{EF}$ の算出は,「生物 生産力のある土地面積」という共通の単位が用いられ, $\mathrm{CO}_{2}$ 固定用森林 $E F_{\mathrm{CO} 2}(\mathrm{EF}$ の分野ではカーボン・フットプリント と呼ばれる), 耕作地 $E F_{\text {crop }}$, 漁場 $E F_{\text {fishing, }}$ 森林地 (パルプ.

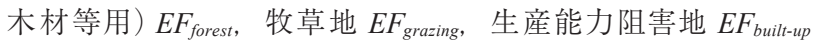
の6種のコンポーネントに分けられる。すなわち,

$E F=E F_{\text {CO2 }}+E F_{\text {crop }}+E F_{\text {fishing }}+E F_{\text {forest }}+E F_{\text {grazing }}+E F_{\text {built-up }}$ (1)

それに基づく 1996 ～ 2010 年の消費による日本の国民 1 人 当たりの $\mathrm{EF}$ 值の推移（6種の土地利用のコンポーネントを 含む）はFig. 1のようになる。1996 年の $\mathrm{EF}$ 值の 5.94 gha/ 人から減少傾向がみられ, 2010 年には $3.90 \mathrm{gha} /$ 人になっ たが，これは世界で 42 番目に大きな值であり，世界平均の バイオキャパシティ（環境収容力）である約 1.7 gha の約 2.3 倍である。

2010 年に掞ける日本の国民 1 人当たりの $\mathrm{EF}$ 值 (単位 gha） ${ }^{15)}$ の各コンポーネントの值を Table 1 に示す。 $E F_{C O 2}$ の 割合が最も大きく全体の $65 \%$ を占め, 次いで $E F_{\text {crop }}$ と $E F_{\text {fishing }}$ がそれぞれ $12 \%, E F_{\text {forest }}$ が $6 \%, E F_{\text {grazing }}$ が $4 \%, E F_{\text {built-up }}$ が $1 \%$ となっている。

\section{2 都道府県の $\mathrm{EF}$ 值の算出}

47 都道府県の $\mathrm{EF}$ 值は, Table 1 の各コンポーネントの $\mathrm{EF}$ 值 ${ }^{15)}$ を Table 2 に示す各 EF のコンポーネントの評価に必要 な消費デー夕から，次式により都道府県別の 1 人当たりの消 費デー夕 $C_{j}$ を全国平均の 1 人当たりの消費デー夕に基づい て按分し，その総和を求めることによって得た。

$$
E F_{i}^{j}=\frac{C_{j}}{\sum_{j=1}^{47} C_{j} p_{j}} \cdot P \cdot E F_{j}
$$

ここで, $E F_{i}^{j}$ は都道府県 $j$ の $E F_{i}$ の值 (gha/人・年),$P$ は全 国の人口 (人), $p_{j}$ は都道府県 $j$ の人口 (人) である。生産能 力阻害地 $E F_{\text {built-up }}$ の定義は, 道路や建物の建設などの開発 事業によって生産力がほぼ失われた土地である。日本の統 計データでは都市計画区域があるが, 生産能力阻害地に厳 密に対応するデー夕は存在しない。 


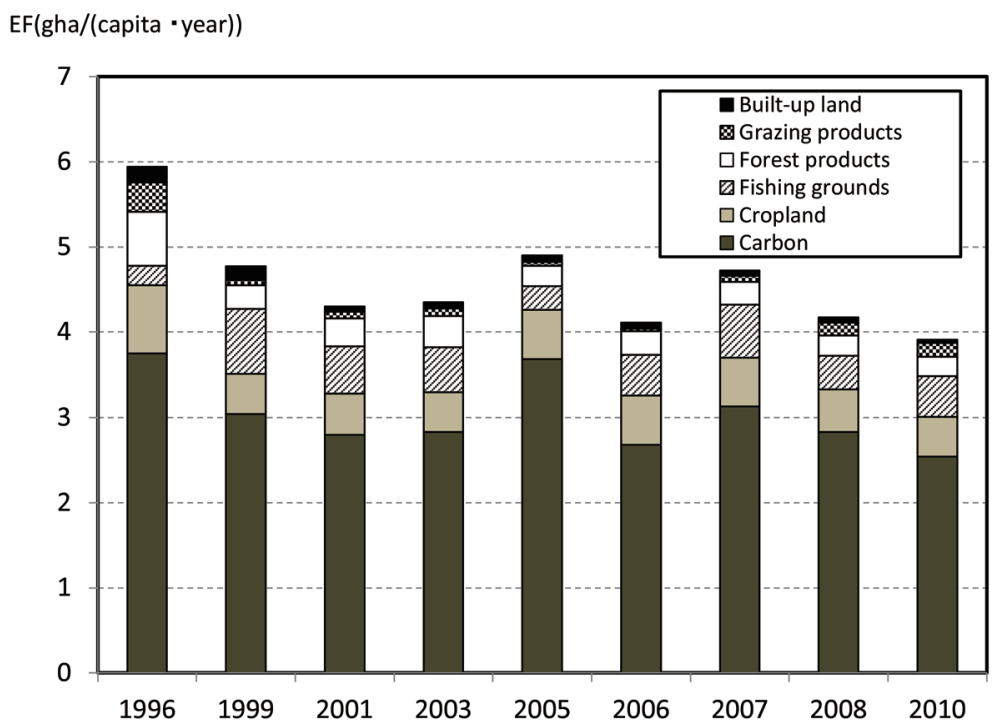

Fig. 1 Time trend of EF values in Japan (1996 2010 year)

Table 1 EF value and its components of Japan in 2010 year ${ }^{15)}$

\begin{tabular}{rr|c}
\hline \multicolumn{2}{c|}{$\mathrm{EF}$ value } & gha/capita $\cdot$ year \\
\hline (total) & & 3.90 \\
\hline (component) & $\mathrm{EF}_{\mathrm{CO} 2}$ & 2.54 \\
\hline & $\mathrm{EF}_{\text {crop }}$ & 0.47 \\
\hline & $\mathrm{EF}_{\text {fishing }}$ & 0.47 \\
\hline & $\mathrm{EF}_{\text {forest }}$ & 0.23 \\
\hline & $\mathrm{EF}_{\text {grazing }}$ & 0.16 \\
\hline & $\mathrm{EF}_{\text {builtup }}$ & 0.04 \\
\hline
\end{tabular}

Table 2 Data source for calculating prefectures' EF components

\begin{tabular}{|c|c|c|}
\hline EF component & Data by prefecture & Data source \\
\hline Carbon & $\begin{array}{l}\text { Final energy consumption (Industry + ResCom + Transportation) } \\
\text { per person (tC/(capita } \cdot \text { year)) }\end{array}$ & $\begin{array}{l}\text { Energy Consumption Statistics by Prefecture } \\
\text { (Agency for Natural Resources and Energy) }^{16)}\end{array}$ \\
\hline Cropland & $\begin{array}{l}\text { Bread + Noodles + Other cereals + Fresh vegetables (kg/(capita· } \\
\text { year)) }\end{array}$ & $\begin{array}{l}\text { Family Income and Expenditure Survey } \\
\text { (Statistics Bureau) }{ }^{17)}\end{array}$ \\
\hline Fishing grounds & Seafood consumption $(\mathrm{kg} /($ capita $\cdot$ year $))$ & $\begin{array}{l}\text { Family Income and Expenditure Survey } \\
\text { (Statistics Bureau) }^{17)}\end{array}$ \\
\hline Forest products & $\begin{array}{l}\text { Tissue paper + Toilet paper + Disposable diapers + Textbooks } \\
\text { Study-aid books + Notebooks + Paper products + Printed matter } \\
(\text { Books, Magazines, Newspapers et al.) (Yen/(capita } \cdot \text { year) })\end{array}$ & 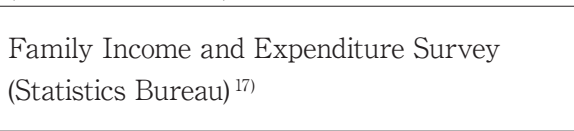 \\
\hline Grazing products & Meat consumption $(\mathrm{kg} /($ capita $\cdot$ year $))$ & 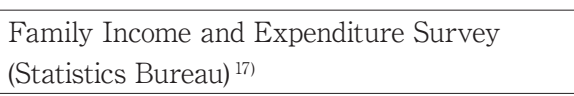 \\
\hline Built-up land & $0.04 \mathrm{gha} /(\mathrm{capita} \cdot$ year $)$ & \\
\hline
\end{tabular}

しかし, $E F_{\text {built-up }}$ は 2010 年の $\mathrm{EF}$ 值のわずか $1 \%$ ありり，全 都道府県の值にあまり大きな差は無いと仮定しても, $E F_{i}^{j} に$ 及ぼす影響はきわめて少ないため, $0.04 \mathrm{gha} /$ 人を割り当てた。

\section{3. 結果と考察}

以上の方法に基づき都道府県別の 2010 年の $\mathrm{EF}$ 值を求め, その成分とともに表示したものを Fig. 2 に示す。 47 都道府 県のなかで山口, 大分, 岡山, 広島の 4 県の $\mathrm{EF}$ 值が突出 して大であり，日本全体の $\mathrm{EF}=3.9$ gha の 2 倍程度の值に なっている。 $\mathrm{EF}$ の成分でみると $E F_{\mathrm{CO} 2}$ がこの 4 県では 80 〜
$85 \%$ と全国平均の $65 \%$ よりかなり高く，これらの県に共通す る要素として製鉄や石油化学コンビナートなどのエネルギー 多消費型の重化学工業が立地し, 大量の $\mathrm{CO}_{2}$ を発生してい る。そのため, 都道府県人口が比較的少ないこれらの県では, 1 人当たりの $\mathrm{CO}_{2}$ 排出量が見かけ上, 多くなるためと考えら れる。

一方, 奈良の $\mathrm{EF}=2.49$ gha が最小であり, $E F_{\mathrm{CO} 2}$ の割合も $45 \%$ と最小である。同様に $E F_{C O 2}$ の割合が低い埼玉, 山梨, 京都，石川，大阪，香川などの $\mathrm{EF}$ が 3 gha 未満である。

WWF Japan では消費土地利用マトリックス (CLUM) と呼 
$\mathrm{EF}($ gha/(capita $\cdot$ year) $)$

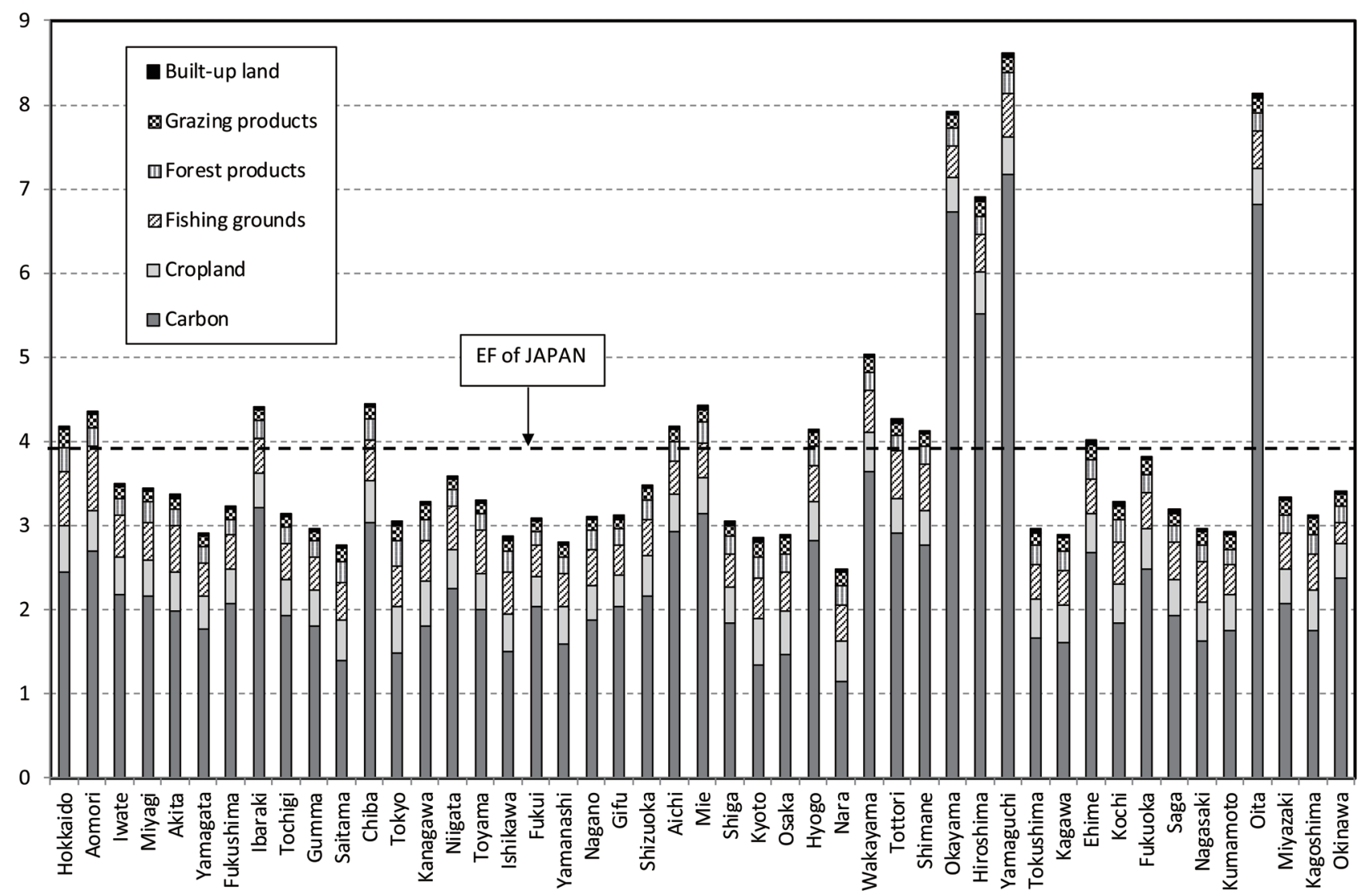

Fig. 2 Comparison of prefectures' EF values in 2010 from consumption data in Table 2

ばれる方法を用いて 2008 年の東京, 愛知, 沖縄の $\mathrm{EF}$ の概 算值を算出している ${ }^{18)}$ 。それによると, 東京と愛知は全国平 均より約 $9 \%, 2 \%$ れぞれ高く, 沖縄県は全国平均より約 9\%低くなっている。本研究では, Fig. 2 のように愛知は全国 平均より約 $7 \%$ 高いが，東京と沖縄は全国平均よりそれぞれ 約 $22 \%, 12 \%$ 低い結果が得られ, 東京都について大きな違 いがみられる。これは Fig. 2 より, 東京都は $E F_{\text {crop }}, E F_{\text {fishing, }}$, $E F_{\text {forest }}, E F_{\text {grazing }}$ の 4 成分は全国平均よりいずれも若干大きい が, $E F_{\mathrm{CO} 2}$ の割合が $42 \%$ と低いことがその要因であると考え られる。

$\mathrm{EF}$ の他の成分では, $E F_{\text {forest }}$ と $E F_{\text {grazing }}$ は寄与が小さく都道 府県間にほとんど差は認められなかった。EF 道 $>$ 京都 $>$ 東京 $>$ 神奈川の順で全国平均より $20 \%$ 以上高く, 福井 $<$ 岐阜<鳥取, 山形, 福島, 茨城の順で平均より $15 \%$ 以上低くなっている。一方, $E F_{\text {fishing }}$ では, 青森 $>$ 北海道 $>$ 鳥 取 $>$ 島根, 秋田の順で全国平均より $20 \%$ 以上高く, 逆に沖 縄 $<$ 岐阜 $<$ 熊本 $<山$ 形, 群馬, 愛知, 福井の順で $20 \%$ 以上 低くなっている。これらはおもに食生活の違いを示している と考えられる。

デー夕源の都道府県別エネルギー消費統計調査では, 人 口当たりの炭素排出量が産業連関表を用いて産業, 民生 (家 庭 + 業務他), 運輸の 3 部門に分けて集計されているため, Fig. 3 には都道府県別の 1 人あたり $\mathrm{CO}_{2}$ 排出量とその内訳を
示した。山口, 大分, 岡山, 広島の 4 県の $\mathrm{CO}_{2}$ 排出量をみると, 民生と運輸からの $\mathrm{CO}_{2}$ 排出はきわめて少ないが, 産業用の エネルギー需要による $\mathrm{CO}_{2}$ 排出がほとんどを占めている。産 業からの $\mathrm{CO}_{2}$ 排出は, 製造業と非製造業に分けられ集計さ れているが，最も EF が大きな山口県では，製造業がそのう ち約 $90 \%$ を占め, 化学・化緎・紙パと鉄鋼・非鉄・窯業土 石がほぼ同量で，製造業からの $\mathrm{CO}_{2}$ の約 $79 \%$ を占めている。 他の大分, 岡山, 広島県では, 鉄鋼·非鉄・窯業土石の割

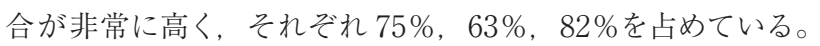
これらの県では, 人口規模がそれほど多くないため, 臨海 部に重化学工業地帯を有する茨城, 千葉, 愛知, 三重県な どに比べ相対的に $\mathrm{EF}$ 值が高くなっていることになる。 $\mathrm{CO}_{2}$ 排出量の多い高炬による製鉄業や石油化学コンビナート等の 立地による産業からの $\mathrm{CO}_{2}$ 排出量を, 最終エネルギー消費と して各都道府県に割り当てるのは, その都道府県だけで消 費するわけではなく, 大部分が他地域で消費され, 他地域 と密接に連関している点を考慮する必要性がある。環境省 によると ${ }^{19)}$ ，鉄鋼業は 2014 年度に約 1.73 億 $\mathrm{t}$ の $\mathrm{CO}_{2}$ を排出 し, 産業界の約 $51 \%$, 日本全体の $\mathrm{CO}_{2}$ 排出量の約 $13.7 \%$ を 占めており, $\mathrm{CO}_{2}$ 排出を抑える水素還元など次世代製鉄装置 の開発が急務である。

Hasegawa ら ${ }^{9)}$ は, 都道府県別の $\mathrm{CO}_{2}$ 排出量を生産と消 費の両面から求めている。それによると, 都道府県別の全 


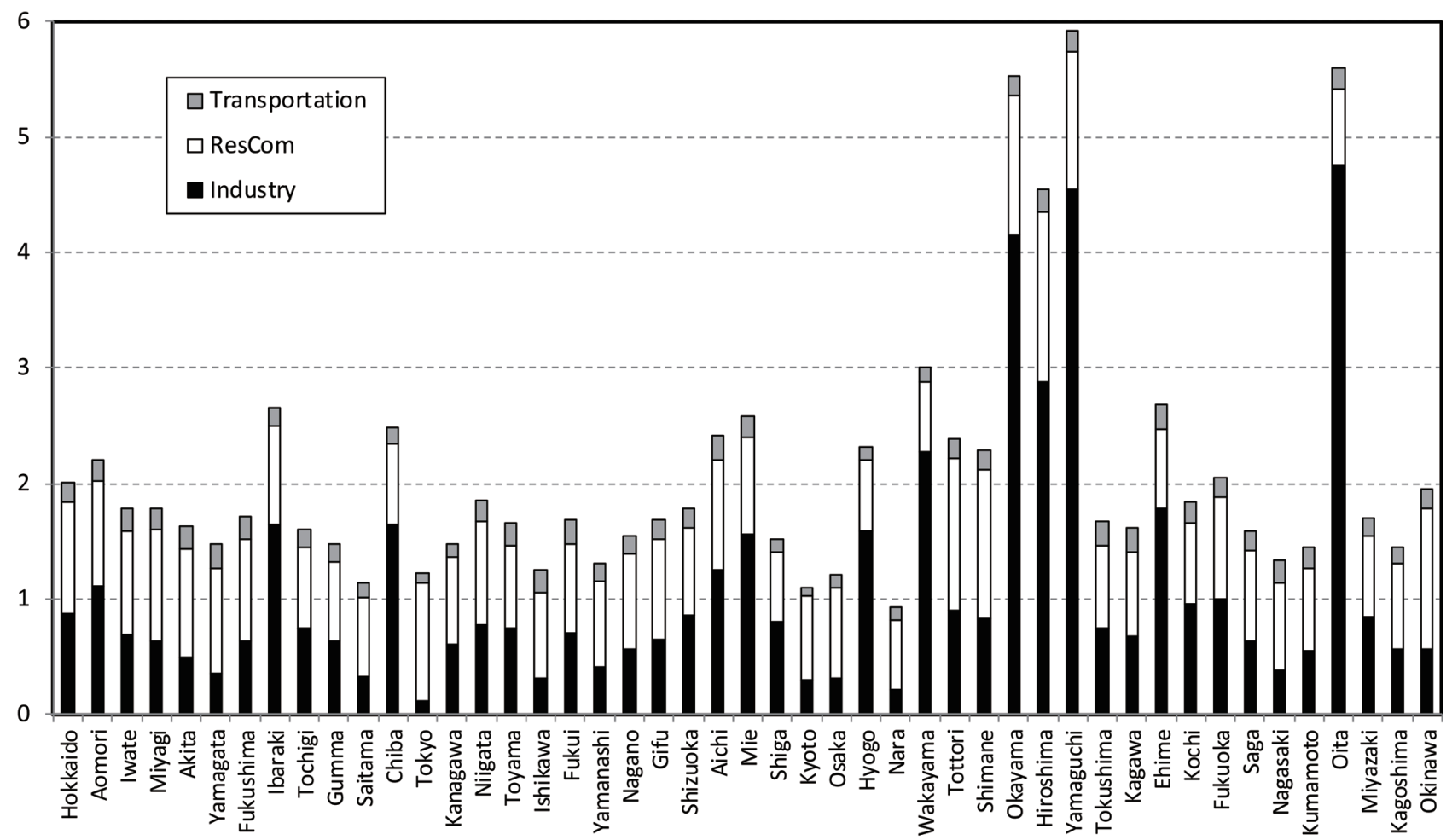

Fig. 3 Prefectures' component of $\mathrm{CO}_{2}$ emissions in 2010

排出量は千葉が最大で, 次いで東京, 愛知, 神奈川, 大阪 の順である。一方, 1 人当たりの $\mathrm{CO}_{2}$ 排出量は, 生産面で は福井県が最大で, 以下, 福島, 大分, 岡山, 山口, 茨城, 広島, 千葉の順である。消費面では東京, 三重, 愛知, 石川, 愛媛の順である。本研究では, 福井と福島は 1 人当たりの $\mathrm{CO}_{2}$ 排出量が 47 都道府県の平均程度であり, 産業, 民生, 運輸の 3 面からこの 2 県が 1 人当たりの $\mathrm{CO}_{2}$ 排出量において 全国で1，2位を占める要因は見当たらないため，Fig. 3 の結 果は妥当であると考えられる。

また，山村 20) は，温室効果ガス排出量算定・報告制度な らびにエネルギー消費統計のデー夕に基づき，製造業に係る $\mathrm{CO}_{2}$ を比較している。温室効果ガス排出量算定・報告制度 のデータには未公開の部分があるが, 愛知県が最大の $\mathrm{CO}_{2}$ 排出県であり，エネルギー消費統計のデータでは千葉県が最 大の $\mathrm{CO}_{2}$ 排出県である。Fig. 3 の結果に都道府県の人口を 乗じると, 愛知県が最大の $\mathrm{CO}_{2}$ 排出県であり, 次いで東京, 千葉, 神奈川, 兵庫, 広島, 北海道, 岡山, 大阪, 福岡の 順（図表割愛）となり，山村 ${ }^{19}$ ) の結果とほぼ類似した傾向 が認められた。

民生 (ResCom) からの $\mathrm{CO}_{2}$ が突出して多いのは, 鳥取, 島根, 岡山, 広島, 山口, 沖縄県の 5 県であり, 特に中国 地方の 5 県はいずれも他の都道府県の 1.5 倍ほどの值になっ ている。民生は, デー夕源では家庭と業務他の 2 つに分類 されているが，それら 6 県では家庭と業務他の両面で 1 人当 たり $\mathrm{CO}_{2}$ 排出量が多く，6県平均で家庭が $0.63 \mathrm{tC} /$ 人・年,

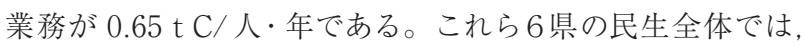

東京, 神奈川, 静岡, 愛知, 大阪, 福岡など人口や産業が 集中している都道府県の約 2 倍の值となっている。また寒冷 で冬場の暖房に化石エネルギーを多量に消費する北海道や 東北地方の各県と比べても約 $25 \%$ 家庭からの $\mathrm{CO}_{2}$ 排出量が 多くなっている。沖縄を除き, 中国地方 5 県のライフスタイル が $\mathrm{CO}_{2}$ 排出という面でやや特異なものであることが推測され るが, その理由については電力使用量や灯油消費量だけで は説明がつかず, 現時点では未解明である。一方, 運輸か らの $\mathrm{CO}_{2}$ は，絶対量は少なく $\mathrm{EF}$ に与える影響はごくわずか であるが, 東京, 神奈川, 滋賀, 京都, 大阪, 兵庫などの 大都市圈が比較的少なく, 秋田, 山形, 福島, 富山, 石川, 福井, 愛知, 徳島, 香川, 愛媛などの地方が大きくなる傾 向が認められる。

2010 年の各都道府県の $E F_{i}^{j}$ 值に都道府県人口 $p_{j}$ を乗じる と, 各都道府県の「総環境負荷量」が土地面積に換算して 求められる。その計算によって求めた結果を Fig. 4 に示す。 この結果から, 東京, 千葉, 神奈川, 愛知, 大阪, 兵庫, 北海道を初めとする人口規模の大きな都道府県で総環境負 荷量が大きくなっていることが明らかである。山口，大分， 岡山, 広島の 4 県は人口規模がやや小さいため, 総環境負 荷量は小さくなるが, 人口規模が同程度の都道府県に比べ て総環境負荷量はかなり大きくなっている。

以上, 都道府県別の消費データから 1 人あたりの $\mathrm{EF}$ 值と 総環境負荷量を論じた。その結果, 重化学工業が立地して いる人口規模があまり大きくない地方の県では，1人あたり の $\mathrm{EF}$ 值が相対的に大きくなることが明らかになった。した 
Total EF (106ha/year)

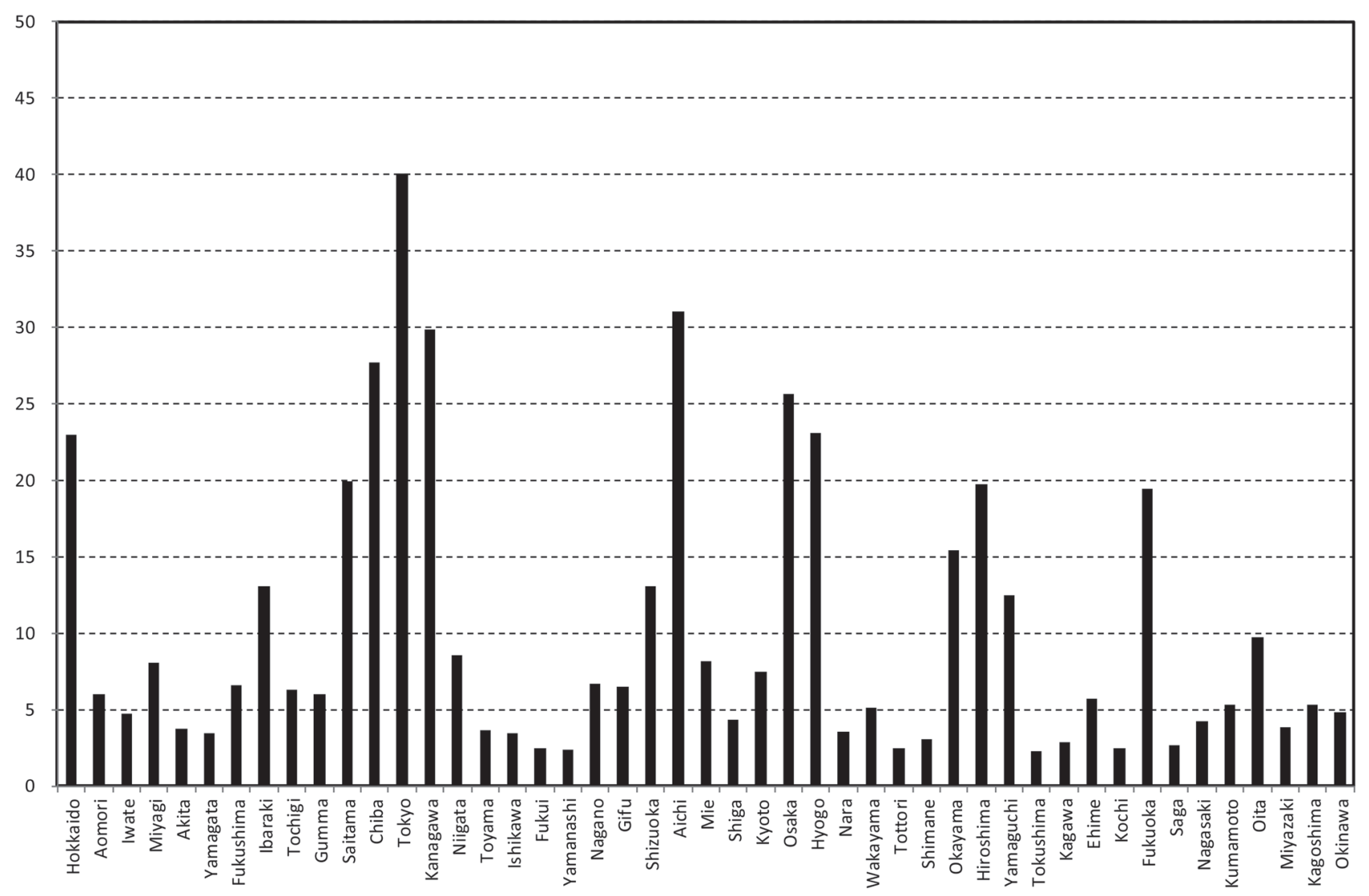

Fig. 4 Total prefectures' EF values in 2010 without corrections for industrial $\mathrm{CO}_{2}$ emissions

がって, 都道府県レベルでの地域の持続可能性を達成する ための適正な $\mathrm{EF}$ 評価として, 産業によるエネルギー消費 $\left(\mathrm{CO}_{2}\right.$ の排出量）を 47 都道府県でどう分配するかが問題となる。

一般に重化学工業など環境負荷の大きな産業は, 基幹産 業として日本全体の種々の産業と密接な関係がある。そこで, 本論文では各都道府県の産業からのエネルギー消費は, 47 都道府県の産業からの $\mathrm{CO}_{2}$ 排出量の平均值を用いて $\mathrm{EF} の$ 再評価を試みた。なお, 岡山県津山市の $\mathrm{EF}$ 值の評価 ${ }^{11)} に$ おいては, 産業・業務系用途の環境負荷は対象外とされた。 その取扱いによる都道府県別の $\mathrm{EF}$ 值と総環境負荷量をそ れぞれ Fig. 5, Fig. 6 に示す。各都道府県の EF 值は, 全国 平均の 3.90 に近い值に平準化されることがわかった(Fig. 5)。 このことは, われわれの日常生活における環境負荷は生活ス タイルの画一化が進み, それほど大きな差がないことを意味 している。

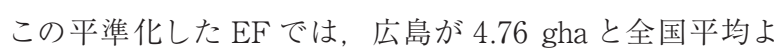
り約 $20 \%$ 大きく最大で, 以下, 鳥取, 島根, 北海道, 山口, 青森, 岡山, 東京の順となった。このうち, 北海道, 青森, 東京は $E F_{\mathrm{CO} 2}$ の值が平均より $5 \%$ 程度高く, さらに北海道は

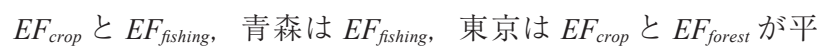
均より 20 〜 $60 \%$ 以上高くなっている。この $\mathrm{EF}$ が全国平均 より大きなグループには, 民生からの $\mathrm{CO}_{2}$ 排出量が全国平 均より約 $40 \sim 75 \%$ 多い中国地方の5県全てが属している。
一方, EF が小さな都道府県では, 滋賀が 3.36 gha と全 国平均より約 $15 \%$ 小さく, 次いで群馬, 兵庫, 奈良, 栃木, 和歌山, 福井, 熊本の順になった。これらの県では $E F_{C O 2}$ が低い值であることが共通の要因であり, 他のコンポーネン トは全国平均と大きな差は認められない。

総環境負荷量 (Fig. 6) の結果を産業部門からの $\mathrm{CO}_{2}$ 排 出量の平均化を図らなかった Fig. 4 の結果と比べると, 人 口規模の影響がより大きく出ていることがわかる。特に岡山, 山口, 大分の 3 県の EF 值が Fig. 6 では，Fig. 4 よりかなり 低下したものとなった。

\section{4. 結 論}

人間活動にともなう持続可能な環境負荷を評価する指標 として，これまで国などグローバルなレベルで環境負荷の計 測に用いられているエコロジカル・フットプリント $(\mathrm{EF})$ を都 道府県等の地域レベルで算出する方法を提案した。日本の 国民1人あたりの EF 值は, Global Footprint Networkの公 表しているデータから入手した。各都道府県については, 国 勢調査の都道府県人口, 世帯人数のほか, $\mathrm{CO}_{2}$ 排出量, 肉 や野菜, 魚消費量, 紙消費量などの消費デー夕を収集・解 析した。次に, 各都道府県の活動における $\mathrm{EF}$ 值を, 該当 地域に対応する消費データを用いて EF の 6 種の構成要素別 に, 日本全体の值を按分して各都道府県の EF 值を決定した。 
$\mathrm{EF}($ gha/(capita· year))

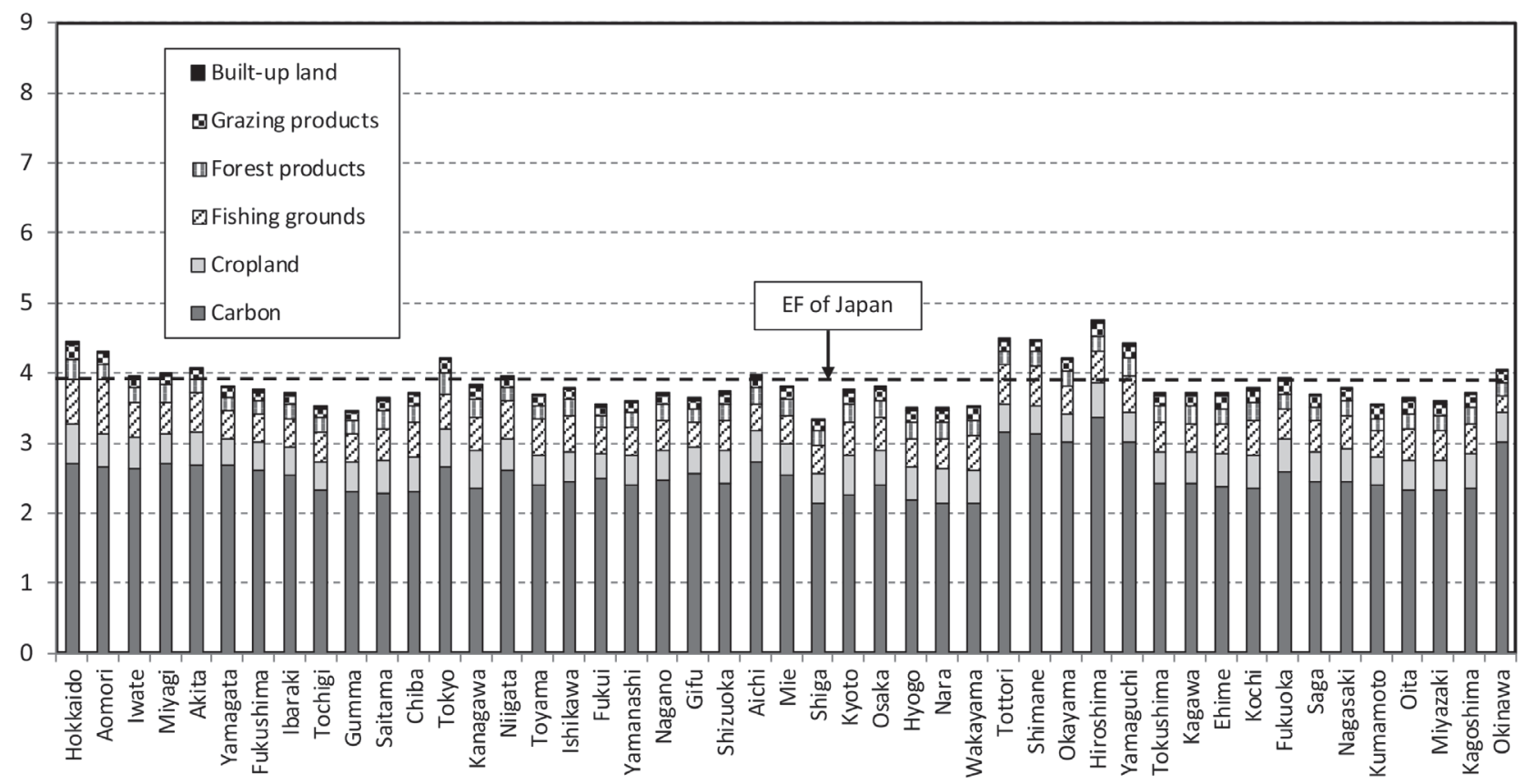

Fig. 5 Prefectures' EF values in 2010 from consumption data using average values of industrial $\mathrm{CO}_{2}$ emissions

Total EF (10 gha/year)

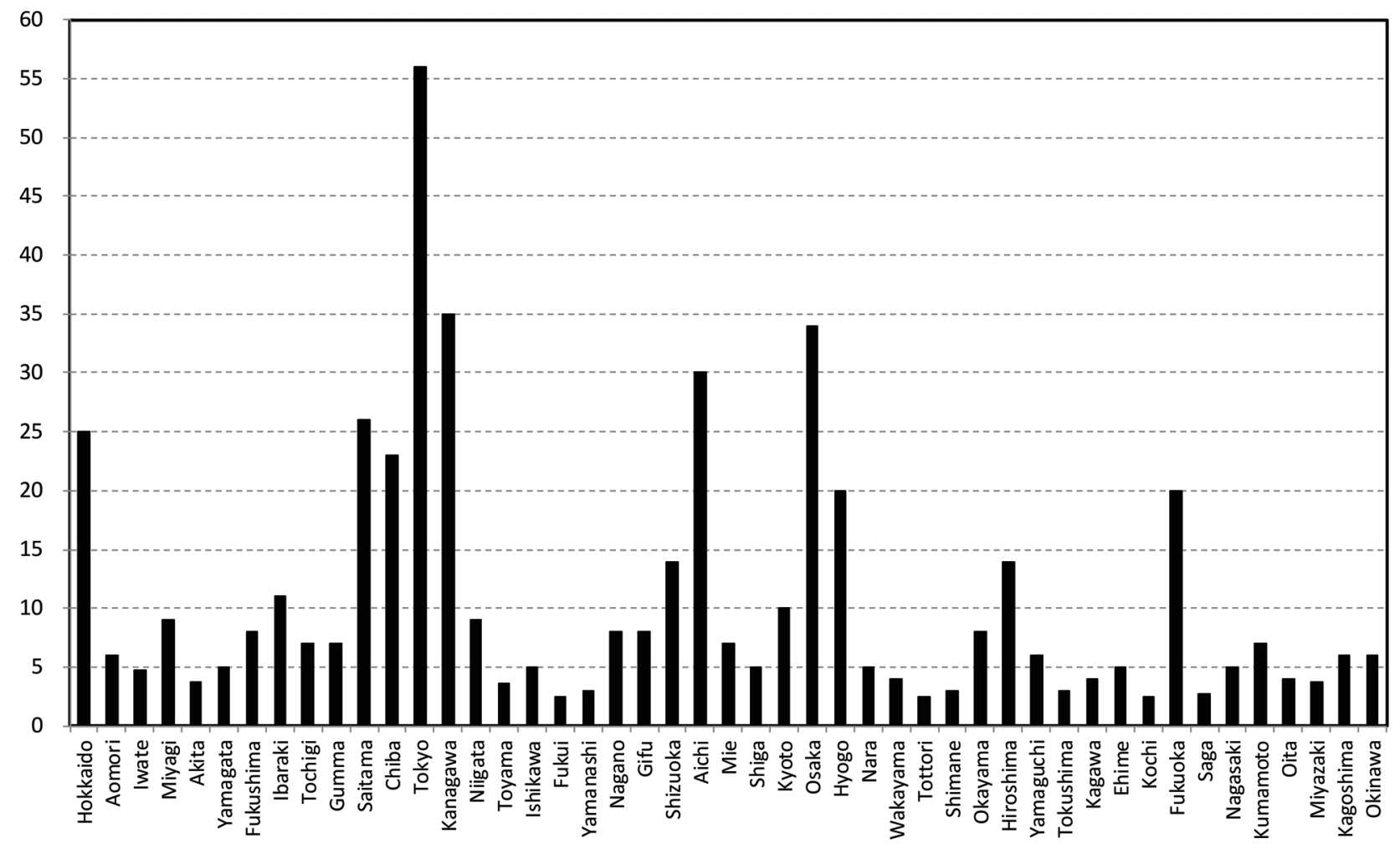

Fig. 6 Total prefectures' EF values in 2010 using average values of industrial $\mathrm{CO}_{2}$ emissions 
その結果，新たな知見として鉄鋼や石油化学などエネルギー 多消費型の重化学工業の割合の高い都道府県の $\mathrm{EF}$ 值は他 の地域に比べてきわめて高く, 東京や大阪のような大都市圈 では EF 值が全国平均より低い傾向があることが分った。

\section{文 献: References}

1) Wackernagel, M.; Rees, W. E., Our Ecological FootprintReducing Human Impact on the Earth, New Society Publishers, 1996

2) Chambers, N.; Wackernagel, M.; Simmons, C., Sharing Nature's Interest: Ecological Footprints as an Indicator of Sustainability, Earthcan Publications, 2001

3) Wada, Y., Research on the Scientific Basis for the Sustainability, Part 5, Chap.3, pp. 248-263, E-Square Incorporated, 2005 : 和田喜彦, エコロジカル・フットプリ ントでみる『環境収容力』, 北川正恭・山本良一他編著, サ ステナビリティの科学的基礎に関する調査報告書，第 5 部 第3 章, pp. 248-263, 267-271，（株）イースクエア内・サス テナビリテイの科学的基礎に関する調査プロジェクト事務 局, 2005

4) Nakano, K., Environ. Sci., 22, 273 (2009) : 中野桂，環境科 学会誌, 22, 273 (2009)

5) Wada, Y.; Kishi, M., Glossary: Application Examples of Ecological Footprint in the World-Focused on Examples in Europe, England and Wales, Chambers, N.; Wackernagel, M.; Simmons, C.; Goto, M., Sharing Nature's Interest: Ecological Footprints as an Indicator of Sustainability, Intershift, p. 224-235, 2005 : 和田喜彦, 岸基史, 解説 : 世界のエコロジカル・フットプリントの活用 事例一欧州·英国・ウェールズの事例を中心に一，ニッキー・ チェンバース, クレイグ・シモンズ, マティース・ワケナゲル, 五頭美和，エコロジカル・フットプリントの活用：地球 $1 コ$ 分の暮らしへ, インターシフト, pp. 224-235, 2005

6) Wada, Y., Environ. Res. Quart., (152), 14 (2009) : 和田喜彦, 季刊環境研究，(152), 14 (2009)

7) Tokyo Metropolitan Government, Tokyo Environmental Outlook 2000, p. 7, 2000 : 東京都環境局, 東京都環境白 書 2000, p.7, 2000

8) Taniguchi, M.; Abe, H.; Shigekane, K., Stud. Reg. Sci., 34, 23 (2004) : 谷口守, 阿部宏史, 重兼薰, 地域学研究, 34
$23(2004)$

9) Yokawa, M.; Kagaya, S.; Hagiwara, R.; Uchida, K., Stud. Reg. Sci., 38, 939 (2008) : 余川雅彦，加賀屋誠一，萩原亨， 内田賢悦，地域学研究, 38, 939 (2008)

10) Hasegawa, R.; Kagawa, S.; Tsukui, M., J. Econ. Struct., 4, 5 (2015)

11) Ujihara, T.; Taniguchi, M.; Matsunaka, R., Environ. Systems Res., 36, 207 (2008): 氏原岳人，谷口守，松中亮治， 環境システム研究論文集, 36, 207 (2008)

12) Nakano, K.; Wada, Y., Sci. Environ. Sustain. Soc., 4, 11 (2007): 中野桂, 和田喜彦, 滋賀大学環境総合研究センター研究 年報, 4, 11 (2007)

13) Ujihara, T.; Taniguchi, M., Proc. Jpn. Soc. Civil Eng., 66, 300 (2010) : 氏原岳人, 谷口守, 土木学会論文 D, 66, 300 (2010)

14) Tanabe, K.; Suzuki, T., J. Jpn. Inst. Energy, 93, 1205 (2013): 田辺和俊，鈴木孝弘，日工齐誌, 93, 1205 (2013)

15) WWF, Living Planet Report 2014, https://www.wwf. or.jp/activities/lib/lpr/WWF_LPR_2014.pdf (Last accessed on 2016/4/01)

16) Agency for Natural Resources and Energy, Energy Consumption Statistics by Prefecture: 経済産業省・ 資源エネルギー庁, 都道府県別エネルギー消費統計調 査, http://www.enecho.meti.go.jp/statistics/energy_ consumption/ec002/ (Last accessed on 2016/4/01)

17) Statistics Bureau, Family Income and Expenditure Survey：総務省統計局，家計調查，http://www.stat. go.jp/data/kakei/ (Last accessed on 2016/4/01)

18) WWF Japan, Japan Ecological Footprint Report 2012, $36(2012)$

19) National Institute for Environmental Studies, The GHG Emissions Data of Japan: 国立環境研究所, 日本国温 室効果ガスインベントリ報告書, 2016, http://www-gio. nies.go.jp/aboutghg/nir/nir-j.html (Last accessed on 2016/4/01)

20) Yamamura, M., Research Reports, School of Human Science and Environment, University of Hyogo, 11, 157 (2009) : 山村充, 兵庫県立大学環境人間学部研究報告, 11 , 157 (2009) 